\title{
Measurement of Foot Bone Mineral Density in Rheumatoid Arthritis: Its Application and Clinical Relevance
}

\author{
Romatoid Artritli Hastalarda Ayak Kemik Mineral Yoğunluğunun Ölçülmesi: \\ Yöntemin Uygulanması ve Klinik Önemi
}

\author{
Ayhan Kamanlı1, Özlem Suluhan¹, Salih Özgöçmen¹, Arzu Kaya¹, ismail Çiftçi², Özge Ardıçoğlu \\ 1Fırat Üniversitesi Tıp Fakültesi, Fizik Tedavi ve Rehabilitasyon Anabilim Dalı, Romatoloji Bilim Dalı, Elazığ, Turkey \\ 2 Kayseri Eğitim ve Araştırma Hastanesi, Nükleer Tıp Kliniği, Kayseri, Turkey
}

\section{Abstract}

Objective: Hand and foot joints are the primary targets in rheumatoid arthritis (RA) and decrease in the periarticular bone mineral density (BMD) is one of the earliest and considerable change in the affected joint. This study aimed to assess the relationship between foot bone mineral density (fBMD) measured by Dual Energy X-ray absorptiometry (DEXA) and BMD at axial sites, disease activity, functional status and quality of life in patients with RA

Materials and Methods: 50 patients with RA, 40 age- and sexmatched patients with osteoarthritis (OA) and 14 voluntary healthy individuals were included in the study. C-reactive protein, erythrocyte sedimentation rate (ESR), Ritchie Articular Index (RAI), Health Assesment Questionnare (HAQ), and Foot Function Index (FFI) were measured. X-ray of the feet was scored by Larsen and Sharp/van der Heijde methods. Axial and fBMD were measured by DXA.

Results: The results of the present study revealed that Turkish patients with RA carrying SE with HLA-DRB1 genes is significantly related with the production of anti-CCP. The diagnostic sensitivity and specificity of anti-CCP for RA is determined as $73,3 \%$ and $100 \%$ respectively.

Conclusion: These results suggest for the first time that foot BMD measurement by DEXA is a useful and precise method. Foot BMD may reflect both localized and generalized bone loss and may be a potential outcome measure particularly in patients with marked foot involvement. (Turk J Rheumatol 2010; 25: 56-62)

Key words: Foot, bone mineral density, DEXA, rheumatoid arthritis

Received: 11.09 .2008

Accepted: 29.01.2009

\section{Özet}

Amaç: Romatoid artritte (RA) el ve ayak eklemleri genellikle öncelikli olarak etkilenmektedir. Periartiküler kemik mineral yoğunluğundaki (KMY) değișiklikler ise bu hastalığın en erken ve dikkati çeken radyolojik bulgularındandır. Bu kontrollü çalıșmada RA'lı hastalarda geliștirdiğimiz bir yöntemle DEXA ile ayak KMY'si, aksiyel iskelet KMY'si, hastalık aktivitesi, fonksiyonel durumu ve yașam kalitesi ile ilișkileri değerlendirilmiștir.

Yöntem ve Gereçler: Çalıșmaya 50 RA'lı hasta ile yas ve cins olarak eșleștirilmiș $40 \mathrm{OA}^{\prime}$ ।ı hasta ve 14 gönüllü sağlıklı birey alındı. Hastaların C-reaktif protein düzeyi, eritrosit sedimantasyon hızı, Ritchie artiküler indeksi (RAi), sağlık sorgulama anketi (HAQ), ayak fonksiyon indeksi (FFi) ölçüldü. Ayak grafileri Larsen and Sharp/van der Heijde yöntemi ile skorlandı. Aksiyel ve ayak KMY'leri Lunar dansitometre cihazında DEXA yöntemi ile ölçüldü.

Bulgular: Ayak KMY'leri kısa dönem tutarlılığı 14 sağlıklı bireyden 3 kez tekrarlanan ölçümle hesaplandı, yüzde değișim katsayısı \% 2.18 olarak oldukça uygun bulundu. Her iki ayak ve aksiyel (spinal ve kalça) KMY kontrollere göre anlamlı bir șekilde düșüktü. Sağ ayak KMY ile aksiyel KMY anlamlı șekilde ilișkiliydi. Ancak hastalık süresi ile aktivite indeksleri (RAi ve FFi) arasında ilișki yoktu. Her iki ayak total KMY ile Sharp eklem mesafe ve erozyon skoru (SEMS ve SES) arasında negatif bir iliskki varken Larsen skoru ile ilișki bulunamadı. Ayak KMY ile el SEMS, SES ve Larsen skoru arasında anlamlı düzeyde negatif bir ilișki bulundu.

Sonuç: Bu sonuçlar DEXA ile ilk kez yapılan ayak KMY ölçümünün kullanıșlı ve geçerli bir yöntem olduğunu göstermiștir. RA'li hastalarda, ayak KMY ölçümü hem bölgesel hemde yaygın kemik kaybını yansıtabilir ve özellikle ayak tutulumu olan hastalarda potansiyel bir sonuç ölçümü olarak kullanılabilir.

(Turk J Rheumatol 2010; 25: 56-62)

Anahtar sözcükler: Ayak, kemik mineral yoğunluğu, DEXA, romatoid artrit

Alındığı Tarih: 11.09.2008 Kabul Tarihi: 29.01.2009 


\section{Introduction}

Rheumatoid arthritis (RA) is a chronic systemic inflammatory auto-immune disease characterized by persistent joint inflammation resulting in joint damage and loss of function. Numerous studies have shown that substantial irreversible damage occurs within the first 2 years, as evidenced by the maximal rate of erosive joint disease during this period (1-3).

Radiological osteopenia of the hands is one of the requirements of American College of Rheumatology (ACR) classification criteria for RA (4). However, X-ray examination is unable to detect bone loss when it is less than 30\%. Dual energy X-ray absorptiometry (DEXA) appears to be a more sensitive method in detecting early bone loss in patients with RA. The relationship between $B M D$, disease duration and bone damage indicates that the DEXA method may be useful in the evaluation of disease activity and progression $(5,6)$.

Rheumatoid arthritis has a significant effect on foot structure (7) with an estimated prevalence of structural and related problems of up to $50 \%$. Bukhari et al. (8) reported $38 \%$ foot involvement in early and/or late stages of the disease. Priola et al. (9) reported that early forefoot involvement is an indication of aggressive disease.

Periarticular osteoporosis is demonstrated on hands by DEXA at an early stage of the disease. Previous studies reported that DEXA method was a useful and precise method and the DEXA results correlated with radiographic damage in the rheumatoid hands $(10,11)$.

The aim of this study was to investigate the relationship between BMD of the foot, axial BMD, quality of life, functional status and disease activity. We also aimed to better understand the importance of foot involvement in RA and to assess the validity of foot BMD measurement.

\section{Material and Methods}

Fifty RA patients who met 1987 ACR criteria for the classification of RA and 48 age- and sex-matched patients with osteoarthritis (OA) were included in the study. In order to detect the short-term precision for DEXA of the foot, 14 healthy volunteers were participated in the validation study.

Patients were under treatment with corticosteroids, disease modifying anti-rheumatic drugs (i.e. methotrexate, sulphasalazine, etc. or combination) or non-steroid antiinflammatory drugs. Disease activity, disease duration, morning stiffness, and other concomitant disorders were recorded. Routine laboratory studies (complete blood count, C-reactive protein, erythrocyte sedimentation rate, rheumatoid factor etc.) were done. Ritchie Articular Index (RAI), Foot Function Index (FFI) (12), Stoke index, Health Assessment Questionnaire (HAQ), visual analog scale (VAS) of pain were assessed in all patients by the same clinician. Bilateral anteroposterior (AP) radiographs of the hands, posteroanterior (PA) and lateral radiographs of the feet were taken in patients with RA and OA using standard protocols and scored with modified Larsen and Sharp/van der Heijde methods $(13,14)$.

The study was approved by the Local Ethical Committee of our Institution and written informed consent was obtained from all participants.

\section{Foot Function Index}

Foot Function Index (FFI) is an index developed by Budiman-Mak and colleagues to evaluate foot functions in RA patients. It is successfully used in osteoarthritis and plantar fasciitis patients as well. The FFI includes a total of 23 questions and has subscales of pain, disability, and activity limitation. The total score was 10 (12).

\section{Foot BMD by Dual Energy X-ray Absorptiometry Method}

DEXA scans were all performed on a Lunar DPX densitometer. We used the same DEXA methodology for the measurement of hand BMD with an analysis package that was originally developed for the measurement of bone mass of small animals and modified for hand BMD measurements. This method did not require a phantom like the aluminum alloy and Perspex plates preferred in previous studies because the current we used was too low $(150 \mu \mathrm{A})$. We used a collimator of $0.86 \mathrm{~mm}$ and detail mode that had pixels of $1.2 \times 2.4 \mathrm{~mm}$.

Participants sit on a stiff seat placed on the measurement table with hips at 90 degrees of flexion and knees at 120 degrees of semi-flexion. The foot was placed flat (sole facing down and ankle semi-flexed) on the measurement plate along the longitudinal center line of the scan field. The subtalar bones were palpated and defined the starting position of the laser pointer. Scanning began from subtalar bones through the distal parts of the metatarsal bones and proximal phalanges and required approximately $10 \mathrm{~min}$ depending on foot size. The same procedure was repeated for the other foot (Figure 1). The region of interest was subtalar, metatarsal, and phalangeal bones, and it was possible to exclude distal parts of the talar bones during the analysis. The measurements were in grams $/ \mathrm{cm}^{2}$.

\section{Axial BMD Measurements}

Axial (spine and hip) BMD measurements were done on L2-L4, femur neck, Ward's triangle, trochanteric area and total femur using the same machine.

Short-term precision of BMD was detected by repeated measurements of right foot, 1-5. metotarsophalangeal (MTP) region, 2. distal metatars and total foot areas of healthy volunteers (15). The coefficient of variation for total foot areas was $2.18 \%$. After showing that the method is sufficient and safe, similar measurements were done in all patients and the control group. Measurement of each foot lasted approximately for 6 minutes. 


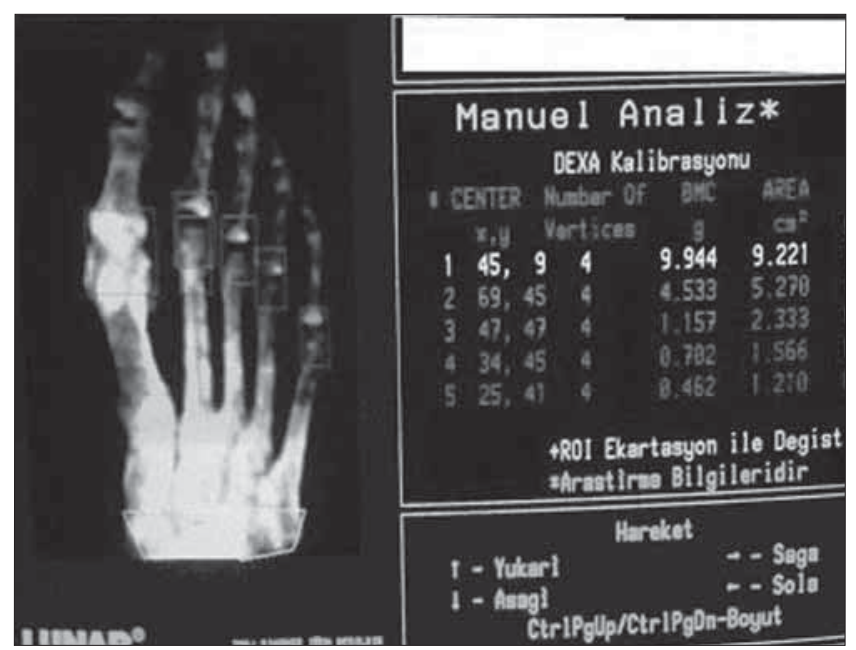

Figure 1. Foot BMD analysis by DEXA
Table 1. Clinical characteristics of the patients with rheumatoid arthritis (RA)

\begin{tabular}{lc}
\hline Parameter & $\begin{array}{c}\text { Patients with RA } \\
(\mathbf{n}=50)\end{array}$ \\
\hline Disease duration (year) & $9.3 \pm 5.8(1-25)$ \\
Morning stiffness (hour) & $1.3 \pm 1.6(0-5.6)$ \\
VAS (cm) (median, range) & $51(12-100)$ \\
HAQ (median, range) & $0.925(0-2.45)$ \\
FFI (median, range) & \\
$\quad$ Pain & $4.52(0-8.94)$ \\
$\quad$ Disability & $4.04(0-8.70)$ \\
$\quad$ Limitation & $2.95(0-8.70)$ \\
$\quad$ Total & $3.68(0-8.57)$ \\
RAI & $21.0 \pm 13.8(0-61)$ \\
Stoke index & $6.6 \pm 4.3(1-17)$ \\
\hline VAS: Visual Analog Scale; HAQ: Health Assessment Questionnaire; \\
RAl: Ritchie Articular Index, FFI: Foot Function Index
\end{tabular}

Table 2. Radiographic scoring (mean \pm SD and range)

\begin{tabular}{lcccccc}
\hline & \multicolumn{2}{c}{ Larsen } & \multicolumn{2}{c}{ Sharp joint narrowing score } & \multicolumn{2}{c}{ Sharp erosion score } \\
& Hand & Foot & Hand & Foot & \multicolumn{2}{c}{ Hand } \\
Rheumatoid arthritis & $49.5 \pm .0 .1$ & $15.6 \pm 8.3$ & $49.7 \pm 16.8$ & $17.3 \pm 7.0$ & $64.7 \pm 20.9$ & $42.4 \pm 18.6$ \\
$(n=50)$ & $(17-111)$ & $(3-36)$ & $(27-109)$ & $(5-38)$ & $(32-131)$ & $(13-98)$ \\
Osteoarthritic controls & $0.9 \pm 1.09$ & $0.5 \pm 0.7$ & $1.2 \pm 1.1$ & $0.9 \pm 0.9$ & 0 & 0 \\
$(n=40)$ & $(0-3)$ & $(0-2)$ & $(0-4)$ & $(0-3)$ & & NA \\
$p$ & $<0.001$ & $<0.001$ & $<0.001$ & $<0.001$ & & NA \\
\hline NA: Not available SD: standart deviation & & & & &
\end{tabular}

\section{Statistics}

Statistical evaluations were done by using SPSS for Windows 10.0 package statistics program (SPSS Inc. Chicago IL USA). For group comparisons $t$ test, Mann Whitney $U$ test and chi-square test were used. The Pearson and Spearman correlation coefficients were used to assess relationship between parameters. Percent coefficient of variation was calculated for short-term precision. All data are presented as mean \pm SD and $\mathrm{p}<0.05$ was considered significant.

\section{Results}

All patients with RA were scored according to Stoke index; 8 and above were included in group 1A (20 female, 0 male); and the others in group 1B ( 25 female, 5 male). In RA group, patients with disease duration $\leq 3$ years were labeled as early RA ( 5 female, 1 male), and the rest were labeled as late RA (40 female, 4 male). In $16 \%$ of patients, disease first manifested with foot complaints. Clinical data of the patients are shown in Table 1.

Foot function index (FFI) was correlated with disease duration ( $r=0.32, p=0.024)$, VAS-pain $(r=0.71, p<0.001)$, morning stiffness $(r=0.58, p<0.001), \operatorname{RAl}(r=0.64, p<0.001)$, Stoke index $(r=0.70, p<0.001)$ and HAQ score $(r=0.87$, $p<0.001)$. There was a negative correlation between age and BMD (Table 5) at all sites however only femur total BMD correlated significantly with FFI $(r=-0.293, p<0.05)$.
Demographic characteristics, BMD values and radiographic scores of the study group are shown in Table 2 and 3. Foot BMD is positively related to L2-L4 spine, femur trochanter, Ward's, neck BMD and age $(p<0.001)$ (Table 4) (Figure 2 and 3)

There was a significant difference between Group1A, Group1B patients regarding FFI, HAQ, RAI $(p<0.001)$ whereas no difference in BMD of axial, total foot and talar and first to fifth MTP regions and 2. MTP distal region. However, a significant difference was confirmed statistically between control group and Group1A patients. There was a negative relation between erythrocyte sedimentation rate $(E S R)$ and first MTF joint BMD $(p<0.05)$. $A$ negative relation between right foot total $B M D$ and RAl was found $(r=0.30, p=0.032$ ). A negative relation was present between both feet total BMD and feet SJNS and SES $(p<0.05)$; and no relation with Larsen score. A negative relation was present between total BMD of the foot and hand SJNS and hand SES and hand Larsen $(p<0.001)$ (Table 6).

\section{Discussion}

Osteoporosis may develop in three distinct patterns as periarticular, marginal erosions and widespread in patients with RA. Generalized bone loss is an early feature of RA and its prevalence is estimated approximately two fold higher than the healthy population $(11,16)$. This early bone loss is more pronounced in hands than in hip and lumbar spine (17-19). 
Table 3. Demographic characteristics and BMD values of the patients

\begin{tabular}{|c|c|c|c|c|}
\hline & & $\begin{array}{l}\text { Rheumatoid arthritis } \\
\qquad(n=50)\end{array}$ & $\begin{array}{l}\text { Osteoarthritis } \\
(n=40)\end{array}$ & $\mathbf{P}$ \\
\hline & Age & $52 \pm 10.9(31-81)$ & $52.4 \pm 11.1(33-77)$ & $>0.05$ \\
\hline & Sex (male/female) & $5 / 45$ & $3 / 37$ & $>0.05$ \\
\hline & Weight (kg) & $67.7 \pm 11,0(43-94)$ & $71.6 \pm 9.0(53-93)$ & $>0.05$ \\
\hline & Height (m) & $1.58(1.36-1.75)$ & $1.57(1.41-1.80)$ & $>0.05$ \\
\hline & BMI $\left(\mathrm{kg} / \mathrm{m}^{2}\right)$ & $26.9 \pm 3.9(18.8-36.3)$ & $29.0 \pm 4.3(21.2-40.5)$ & $<0.05$ \\
\hline & Pre/post-menopausal & $20 / 25$ & $12 / 25$ & $>0.05$ \\
\hline \multirow[t]{21}{*}{$\mathrm{BMD}\left(\mathrm{gr} / \mathrm{cm}^{2}\right)$} & $\mathrm{L}_{2}-\mathrm{L}_{4}$ & $1.02 \pm 0.23$ & $1.11 \pm 0.17$ & 0.049 \\
\hline & Femur Ward's & $0.69 \pm 0.14$ & $0.82 \pm 0.19$ & $<0.001$ \\
\hline & Femur neck & $0.84 \pm 0.12$ & $0.93 \pm 0.15$ & 0.002 \\
\hline & Femur trochanter & $1.03 \pm 0.20$ & $1.14 \pm 0.17$ & 0.009 \\
\hline & Femur total & $0.86 \pm 0.12$ & $0.97 \pm 0.14$ & $<0.001$ \\
\hline & Right foot talar & $0.74 \pm 0.20$ & $0.80 \pm 0.18$ & 0.131 \\
\hline & Left foot talar & $0.71 \pm 0.22$ & $0.78 \pm 0.18$ & 0.120 \\
\hline & Right foot 1. MTP & $0.57 \pm 0.14$ & $0.65 \pm 0.15$ & 0.008 \\
\hline & Left foot 1. MTP & $0.56 \pm 0.15$ & $0.66 \pm 0.15$ & 0.003 \\
\hline & Right foot 2. MTP & $0.32 \pm 0.2$ & $0.36 \pm 0.2$ & 0.014 \\
\hline & Left foot 2. MTP & $0.33 \pm 0.2$ & $0,36 \pm 0,2$ & 0.025 \\
\hline & Right foot 3. MTP & $0.31 \pm 0.2$ & $0,34 \pm 0,2$ & 0.001 \\
\hline & Left foot 3. MTP & $0.33 \pm 0.2$ & $0,32 \pm 0,2$ & 0.312 \\
\hline & Right foot 4. MTP & $0.30 \pm 0.2$ & $0,30 \pm 0,2$ & 0.709 \\
\hline & Left foot 4. MTP & $0.30 \pm 0.2$ & $0,31 \pm 0,2$ & 0.156 \\
\hline & Right foot 5. MTP & $0.29 \pm 0.2$ & $0,31 \pm 0,2$ & 0.026 \\
\hline & Left foot 5. MTP & $0.29 \pm 0.2$ & $0,31 \pm 0,2$ & 0.198 \\
\hline & Right foot 2. MTP (distal) & $0.33 \pm 0.2$ & $0,37 \pm 0,2$ & 0.015 \\
\hline & Left foot 2. MTP (distal) & $0.35 \pm 0.2$ & $0,38 \pm 0,2$ & 0.032 \\
\hline & Right foot total & $0.58 \pm 0.10$ & $0,64 \pm 0,2$ & 0.003 \\
\hline & Left foot total & $0.56 \pm 0.11$ & $0.65 \pm 0.2$ & $<0.001$ \\
\hline
\end{tabular}

\begin{tabular}{|c|c|c|c|c|}
\hline \multirow{3}{*}{ Lumbar $_{2}-$ Lumbar $_{4}$} & \multicolumn{2}{|c|}{ Right Foot Total BMD } & \multicolumn{2}{|c|}{ Left Foot Total BMD } \\
\hline & $\begin{array}{c}\text { RA } \\
(n=50)\end{array}$ & $\begin{array}{l}\text { Control } \\
(n=40)\end{array}$ & $\underset{(n=50)}{R A}$ & $\begin{array}{c}\text { Control } \\
(n=40)\end{array}$ \\
\hline & $40.572 *$ & $0.742 *$ & $0.516^{*}$ & $0.779 *$ \\
\hline Femur neck & $0.752 *$ & $0.737^{*}$ & $0.711 *$ & $0.681 *$ \\
\hline Femur trochanter & $0.674^{*}$ & $0.743^{*}$ & $0.679 *$ & 0.677 \\
\hline Femur ward's & $0.714^{*}$ & $0.725^{*}$ & $0.650 *$ & $0.686^{*}$ \\
\hline Femur total & $0.724^{*}$ & $0.752^{*}$ & $0.694^{*}$ & $0.740 *$ \\
\hline
\end{tabular}

Periarticular bone loss has been demonstrated in certain body areas using different methods (21-22). Hand joints are the target joints in RA and assessment using radiographic or other imaging techniques gives detailed information about disease status and outcome. It is clear that hand BMD measurement using DEXA is a precise, repeatable and reliable method. The hand BMD has been shown to correlate with BMD at other parts of the body (23). Different radiographic scoring methods have been developed to evaluate the disease progression in RA however they had restricted ability to evaluate bone mineralization (23).

Many studies $(18,20,24-26)$ have been published about the assessment of BMD in hand and forearm of RA patients. However to our knowledge, there is no study assessing periarticular and/or total foot BMD in RA using the DEXA method. Foot joints are weight bearing joints and also target for inflammation in RA. BMD measurements of calcaneus by DEXA have been considered to have low long-term consistency (27). However, it was noted that heel DEXA can be used to scan OP in risk groups (28).

Peel et al. (20) reported that the hand BMD was lower with respect to other areas in the postmenopausal patients with RA. Devlin et al. (24) showed correlation between CRP levels, an activity marker, and hand BMD. In our study, there was a negative correlation between right and left foot BMD and ESR.

Shibuya et al. (21) reported that BMD measurements on mid radius and calcaneus were significantly lower in postmenopausal patients with RA than patients with osteoarthritis except BMD at lumbar spine. These authors also showed close correlation between BMD in all areas and severity markers for the disease and body mass.

Shenstone et al. (29) reported correlation between BMD and HAQ score, and also showed relationship between lumbar BMD and baseline Stoke Index. The BMD loss was found to be higher in femur neck in early stages 


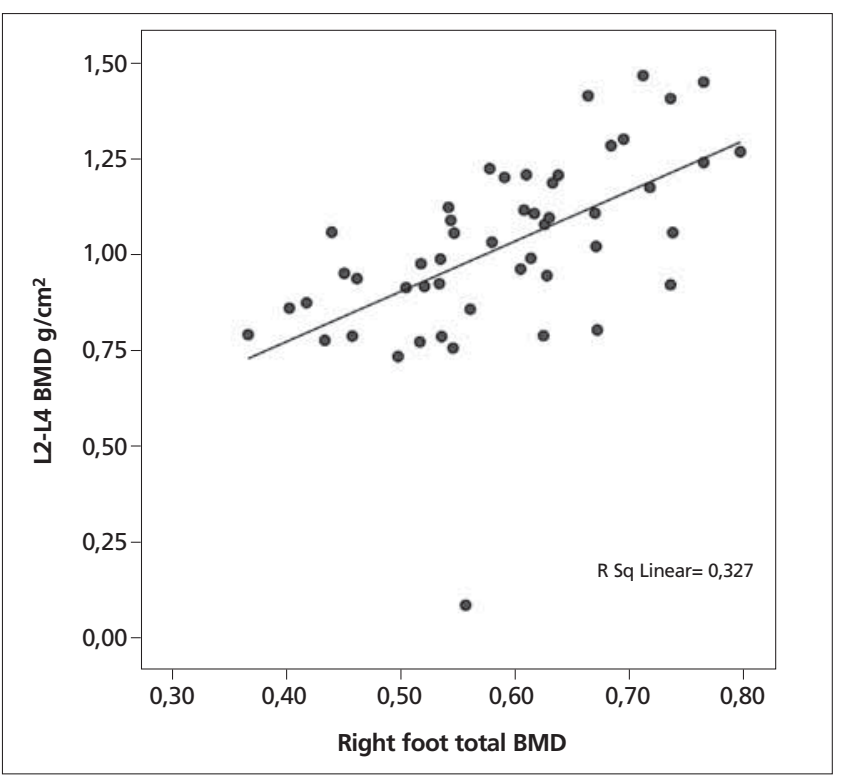

Figure 2. Relationship between right foot and L2-L4 BMD $\left(\mathrm{gr} / \mathrm{cm}^{2}\right)$ in the study group

Table 5. Relationship between age and BMD in patients

\begin{tabular}{|c|c|c|}
\hline & & \\
\hline & RA & Control \\
\hline Lumbar $_{2}-$ Lumbar $_{4}$ & $-0.44 * *$ & $-0.53 * *$ \\
\hline Femur Ward's & $-0.52 * * *$ & $-0.71 * * *$ \\
\hline Femur neck & $-0.59 * * *$ & $-0.71 * * *$ \\
\hline Femur trochanteric & $-0.45 * *$ & $-0.59 * * *$ \\
\hline Femur total & $-0.53 * * *$ & $-0.63 * * *$ \\
\hline Right 1. MTP & $-0.53 * * *$ & $-0.64 * * *$ \\
\hline Left 1. MTP & $-0.56 * * *$ & $-0.44 * * *$ \\
\hline Right 2. MTP distal & $-0.41 * *$ & $-0.46 * *$ \\
\hline Left 2. MTP distal & $-0.37 * *$ & $-0.34^{*}$ \\
\hline Right foot total & $-0.56 * * *$ & $-0.64 * * *$ \\
\hline Left foot total & $-0.50 * * *$ & $-0.59 * * *$ \\
\hline
\end{tabular}

of the RA regardless of disease activity and functional loss. But, in our study, there was no relation between BMD with Stoke Index.

We found that FFI was positively related to disease duration, ESR, VAS pain, morning stiffness, RAI and HAQ. The femur trochanter BMD and FFI were negatively correlated. It is considered that hip BMD is more related to disability, pain and functional limitation in patients with RA in accordance with above mentioned studies.

Ozgocmen et al. (30) compared HAQ and Larsen scores with BMD measurements from axial, total hand and 2.metacarpal middle shaft in 30 RA patients and 29 healthy females, no correlation was found between HAQ and other parameters. They reported that Larsen score had slightly negative correlation with BMD of second. metacarpal middle shaft and the total hand BMD had positive correlation with lomber spine and femur neck BMD. In accordance with the previous studies, we found

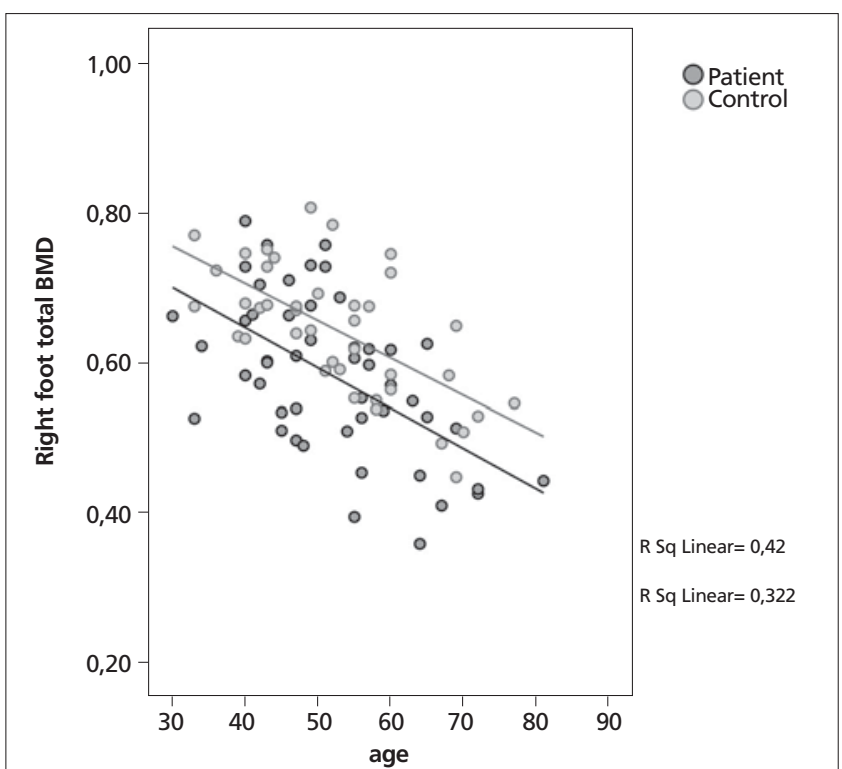

Figure 3. Relationship between right foot total BMD $\left(\mathrm{gr} / \mathrm{cm}^{2}\right)$ and age in the study group

a negative correlation between foot BMD and SJSN and SES but not with Larsen score.

Plain radiographs are routine methods to evaluate joint damage and disease progression in RA. They are beneficial in pursuing natural continuity of disease and detecting treatment. Radiographic evaluation has many advantages. It reflects time of joint pathology and allows repeated evaluations. Also it has advantages like repeatability, highly assessed validity and sensitivity to change (10). Many scoring methods only include hand radiographs; but it was reported that erosions may develop earlier on the foot region of patients with RA (31). Paimela et al. (31) suggested that radiographic modifications of feet are more sensitive than modifications of hand in early RA and for this reason radiographic evaluations should be included in the RA classification criteria. Particularly, diagnostic sensitivity increases when hand and foot radiographs were evaluated together in early disease $(2,26,31-36)$. Foot joints are frequently involved in RA and results in functional limitations. Bone loss in the feet results from combined effects of localized and generalized inflammation. We also consider other concomitant effects like menopausal status and glucocorticoid use. It was noted in most publications that in order to increase sensitivity of radiological criteria, feet should be analyzed along with hands (33). In addition to this, radiological modifications occur in time $(34,35)$.

In our previously published study (10), we measured hand, spine and femur BMD by DEXA in patients with RA and healthy controls. We found a moderate relationship between radiographic scores and hand BMD with Larsen, Sharp/van der Heijde and SENS (simple erosion narrowing score). While the hand BMD was found to be lower in the RA patients, there was no difference between the axial 
Table 6. Relationship between radiographic scores and foot BMD in patients with RA

\begin{tabular}{|c|c|c|c|c|c|c|}
\hline & \multicolumn{2}{|c|}{ Larsen } & \multicolumn{2}{|c|}{ SJNS } & \multicolumn{2}{|c|}{ SES } \\
\hline & Hand & Foot & Hand & Foot & Hand & Foot \\
\hline Right foot total BMD & $-0.558 * *$ & -0.250 & $-0.514 * *$ & $-0.401^{*}$ & $-0.576 * *$ & $-0.375^{*}$ \\
\hline Left foot total BMD & $-0.591 * *$ & -0.278 & $-0.561 * *$ & $-0.427^{*}$ & $-0.602 * *$ & $-0.418^{*}$ \\
\hline
\end{tabular}

BMD. As the hand BMD correlated significantly with disease duration and CRP levels, we suggested that radiographic scores were beneficial in estimating hand BMD (10).

Our results reveal that foot BMD measurement using DEXA is a practical, repeatable and easy method. Foot BMD measurement may reflect both localized and generalized bone loss and may be a potential outcome measure particularly in patients with marked foot involvement.

\section{Conflict of Interest}

No conflict of interest is declared by the authors.

\section{References}

1. Mottonen TT. Prediction of erosiveness and rate of development of new erosions in early rheumatoid arthritis. Ann Rheum Dis 1988; 47: 648-53.

2. van Riel PL, Fransen J. Established rheumaoid arthritis: clinical assessments. Best Pract Res Clin Rheumatol. 2007; 21: 807-25.

3. O'dell JR. Rheumatoid arthritis: the clinical picture. In Koopman WJ (editor) Arthritis and allied conditions. Lippincott Williams and Wilkins, Philadelphia, 2001; 1153-86.

4. Arnett FC, Edworthy SM, Bloch DA McShane DJ, Fries JF, Cooper NS. et al. The American Rheumatism Association 1987 revised criteria for the classification of rheumatoid arthritis Arthritis Rheum. 1988; 31: 315-24.

5. Jensen $T$, Hansen M, Jensen KE Pødenphant J, Hansen TM, Hyldstrup L. Comparison of dual X-ray absorptiometry (DEXA), digital X-ray radiogrammetry (DXR), and conventional radiographs in the evaluation of osteoporosis and bone erosions in patients with rheumatoid arthritis. Scand J Rheumatol 2005; 34: 27-33.

6. Njeh CF, Genant HK. Bone loss quantative imaging techniques for assessing bone mass in rheumatoid arthritis. Arthritis Res 2000; 2: 446-50.

7. Michelson J, Easley M, Wigley FM, Hellmann D. Foot and Ankle problems in rheumatoid arthritis. Foot Ankle Int 1994; 15: 608-13.

8. Van der heijde. Joint erosions and patients with early rheumatoid arthritis Br J Rheumatol 1995; 34 Suppl 2: 74-8.

9. Priolo F, Bacarini L, Cammisa M, Cerase A, Ferrara R, Della Casa-Alberighi $O$. Radyographic chances in the feet of patients with early rheumatoid arthritis. J Rheumatol 1997; 24: 2113-8.

10. Ardicoglu O, Ozgocmen S, Kamanlı A, Pekkutucu I. Relationship between bone mineral density and radiologic scores of hands in rheumatoid arthritis. J Clin Densitom 2001; 4: 263-9.

11. Haugeberg G, Uhlig T, Falch JA, Halse JI, Kvien TK. Bone mineral density and frequency of osteoporosis in female patients with rheumatoid arthritis: results from 394 patients in the Oslo County Rheumatoid Arthritis register. Arthritis Rheum 2000; 43: 522-30.

12. Budiman-Mak E, Conrad KJ, Roach KE. The foot function index: a measure of foot pain and disability. J Clin Epidemiol 1991; 44: 561-70.

13. Boini S, Guillemin F. Radiographic scoring methods as outcome measures in rheumatoid arthritis: properties and advantages. Ann Rheum Dis 2001; 60: 817-27.

14. Van der Heijde DM. Plain X-rays in rheumatoid arthritis: overview of scoring methods, their reliability and applicability. Bailliere Clin Rheumatol 1996; 10: 435-53.

15. Glüer C-C, Blake G, Lu Y, Blunt BA, Jergas M, Genant HK. Accurate assessment of precision errors: how to measure the reproducibility of bone densitometry techniques. Osteoporos Int 1995; 5: 262-70.

16. Alenfeld FE, Diessel E, Brezger M, Sieper J, Felsenberg $D$, Braun J. Detailed analyses in periarticular osteoporosis in rheumatoid arthritis. Osteoporos Int 2000; 11: 400-7.

17. Haugeberg G, Uhlig T, Falch JA, Halse JI, Kvien TK. Reduced bone mineral density in male rheumatoid arthritis patients: frequencies and associations with demographic and disease variables in ninety four patients in the Oslo County Rheumatoid Arthritis Register. Arthritis Rheum 2000; 43: 2776-84.

18. Deodhar AA, Brabyn J, Jones PW, Davis MJ, Woolf AD. Longitudinal study of hand bone densitometry in rheumatoid arthritis. Arthritis Rheum 1995; 38: 1204-10.

19. Haugeberg G, Emery P. Value of Dual-Energy X-Ray Absorptiometry as a diagnostic and assessment tool in early rheumatoid arthritis. Rheum Dis Clin N Am 2005; 31: 715-28.

20. Peel NF, Spittlehouse AJ, Bax DE, Eastell R. Bone mineral density of the hand in rheumatoid arthritis. Arthritis Rheum 1994; 37: 983-91.

21. Shibuya K, Hagino H, Morio Y, Teshima R. Crosssectional and longitudinal study of osteoporosis in patients with rheumatoid arthritis. Clin Rheumatol 2002; 21: 150-8.

22. Kelly CA, Bartholomew P, Lapworth A, Basu A, Hamilton J, Heycock C. Peripheral bone density in patients with rheumatoid arthritis and factors which influence it. Eur J Intern Med 2002; 13: 423.

23. Daragon A, Krzanowska K, Vittecoq O, Ménard JF, Hau I, Jouen-Beades $F$, et al. Prospective $\mathrm{X}$-ray densitometry and ultrsonography study of the hand bones of patients with rheumatoid arthritis of recent onset. Joint Bone Spine 2001; 68: 34-42.

24. Devlin J, Lilley J, Gough A et al. Clinical associations of dual-energy X-ray absorbtiometry measurement of hand bone mass in rheumatoid arthritis. Br J Rheumatol 1996; 35: 1256-62.

25. Deodhar AA, Brabyn J, Pande I, Scott DL, Woolf AD. Hand bone densitometry in rheumatoid arthritis, a five year 
longitudinal study: an outcome measure and a prognostic marker. Ann Rheum Dis. 2003; 62: 767-70.

26. Harrison BJ, Hutchinson CE, Adams J, Bruce IN, Herrick AL. Assessing periarticular bone mineral density in patients with early psoriatic arthritis or rheumatoid arthritis. Ann Rheum Dis 2002; 61: 1007-11.

27. Ito Masako, Nishida A, Kono J, Kono M, Uetani M, Hayashi $\mathrm{K}$. Which bone densitometry and which skeletal site are clinically useful for monitoring bone mass? Osteoporos Int 2003; 14: 959-64.

28. Kirk JK, Nichols M, Spangler JG. Use of a peripheral dexa measurement for osteoporosis screening. Fam Med 2002; 34: 201-5.

29. Shenstone BD, Mahmoud A, Woodward R, Elvins D, Palmer R, Ring $\mathrm{EF}$, et al. Longitudinal bone mineral density changes in early rheumatoid arthritis. Br J Rheumatol 1994; 33: 541-5.

30. Ozgocmen S, Karaoglan B, Kocakoç E, Ardicoglu O, Yorgancioglu ZR. Correlation of hand bone mineral density with the metacarpal cortical index and carpo: metacarpal ratio in patients with rheumatoid arthritis. Yonsei Med J 1999; 40: 478-82.

31. Paimela L. The radiographic criterion in the 1987 revised criteria for rheumatoid arthritis. Reassessment in a prospective study of early disease. Arthritis Rheum 1992; 35: 255-8.

32. Plant MJ, Saklatvala J, Borg AA, Jones PW, Dawes PT. Measurement and prediction of radiological progression in early rheumatoid arthritis. J Rheumatol 1994; 21: 1808-13.

33. Atkinson JP. C-reactive protein: a rheumatologist's friend revisited. Arthritis Rheum 2001; 44: 995-6.

34. Devauchelle-Pensec Saraux A, Alapetite S, Colin D, Le Goff P. Diagnostic value of radiographs of the hands and feet in early rheumatoid arthritis. Joint Bone Spine 2002; 69: 434-4.

35. Goldring SR Pathogenesis of bone erosions in rheumatoid arthritis. Curr Opin Rheumatol 2002; 14: 406-10.

36. Bukhari $M$, Harrison $B$, Lunt $M$, Scott DG, Symmons DP, Silman AJ. Time to first occurrence of erosions in inflammatory polyarthritis: results from a prospective community-based study. Arthritis Rheum 2001; 44: 1248-53. 